\title{
THE RELATIONSHIP BETWEEN THE FORM OF EMPLOYMENT AND EMPLOYEE TRAINING AND DEVELOPING OPPORTUNITIES IN ORGANIZATIONS
}

\author{
Magdalena Kot-Radojewska*
}

\begin{abstract}
In modern organizations, the importance of employee training and development is increasingly emphasized because as it allows them to improve their qualifications and develop new competencies and attitudes useful for the organization. On the other hand, the flexible forms of employment, which are less permanent than indefinite period employment contracts, are increasingly used in organizations. The aim of the paper is to present the relationship between the form of employment and employee training and developing opportunities in organizations. The paper presents the results of research conducted by means of a diagnostic survey, with the use of a questionnaire among 569 employees of the Province of Silesia. A research process was conducted on the basis of grounded theory, and statistical analysis was conducted using the SPSS for Windows, assuming the level of significance at 0.05. In order to compare people with different forms of employment, the Kruskal-Wallis test was used. The research results indicated that there are certain relationships between the form of employment and employee training and development opportunities in the organization. Statistically significant differences were shown between the form of employment and the assessment of employee development opportunities, the form of employment and the assessment of employee promotion opportunities in the organization and the form of employment and the assessment of employee professional development opportunities.
\end{abstract}

Keywords: human capital, professional development, training, form of employment.

\section{INTRODUCTION}

The competitive advantage of modern organizations, which operate in the knowledge-based economy, is determined by intangible resources (Pedrini, 2007), especially knowledge, which is owned by

WSB University. E-mail: mkot@wsb.edu.pl 
the employees of the organization (Becker et al., 1990). Knowledge is the strength of the human capital of the organization and is a key driver of economic growth (Batra, 2009), and knowledge sharing is a factor of achieving organizational success (Burke, 2011). The task of managers is to recognize human potential and create opportunities for their development (Szczepańska-Woszczyna \& Dacko-Pikiewicz, 2014) because this is the best way to strengthen the position of the organization (Psarras, 2006). The survival of the organization in the conditions of high competitiveness is determined by the improvement of human capital towards innovation and efficiency (Falola et al., 2014). Companies have to make increased investment in human resources, who can have a real impact on the efficiency of economic activities of these organizations (Szczepańska-Woszczyna et al., 2015). Employee training may affect their sense of appreciation and satisfaction, motivation to work and commitment (Elnaga \& Imran, 2013). There is also a statistically significant relationship between taking action related to sustainable business in the company and manager's conviction (awareness) regarding the influence of the manager on employees and the stimulation of their behaviour, including their development, decent treatment, communication with the manager, and the system of rewards and promotions (Szczepańska-Woszczyna \& Kurowska-Pysz, 2016).

Opportunities for employee training and development in organizations are analyzed in terms of factors occurring both on the sides of the organization itself (size, industry, organizational culture, etc.) and employees (ambitions, striving for promotion, etc.). However, there are no studies on the relationship between training opportunities that employees have and their form of employment. As attempts are made to make employment in organizations more flexible and the flexible forms of employment, such as contracts of mandate, are increasingly used (Filipowicz, 2006), it is worth asking whether employee training and development opportunities are determined by the form of employment. The research results presented in the paper aim to answer the question which forms of employment form the basis for employee training and development. To this end, a survey was conducted among 569 employees of the Province of Silesia working under indefinite duration employment contracts, fixed-term employment contracts, contracts of mandate, contracts for specific work and those who are self-employed. 
The paper presents an overview of the literature on employee training and development in organizations, the forms of training and development, and the functions they perform in organizations. The methodological assumptions of research and the results obtained were presented, as well as a discussion on the selected results of previous research into employee training and development, with particular emphasis on those related to the increased commitment and performance of employees. Finally, the research summary was presented, and further research areas in this area were indicated.

\section{THEORETICAL BACKGROUND}

The development of employees in the organization can be analyzed from different, individual, group, organizational or social perspectives (Cho \& Won Yoon, 2010). A starting point in the paper is the organizational perspective. The development of employees in the organization can be regarded as a subsystem of a wider system, that is organization human resources management (Szałkowski, 2006). It means the development of the skills of individual employees, which translates into the development of the organization as a whole (Hameed \& Waheed, 2011). R. Griffin defines training as teaching managers and professional employees skills that are necessary at the present and future job position (Griffin, 1996). It involves broadening knowledge and shaping the behavior of employees in order to adapt them to technical, organizational or economic changes taking place in the organization and its environment (Kożusznik \& Adamiec, 2000). Professional development is defined as the process of creating opportunities for developing the professional interests and skills of employees (Matthews et al., 2008), which leads to broadening their knowledge and improving their skills, learning through experience (in practice), developing new beliefs, raising professional qualifications, and cooperation in the field of the mutual learning of employees (Sutherland \& Canwell, 2007). The necessity of permanent employee training results from the dynamic development of knowledge and the fact that it and skills learned become outdated. The forms and methods of employee training must be tailored to their needs and the adopted organizational solutions. The forms include formal education, coaching, mentoring, behavioral modeling, development 
workshops, on-the-job and off-the- job training (Imran \& Tanveer, 2015). Employee training and development result in their higher qualifications and efficiency (Bataineh, 2014), and organizational development (Vinesh, 2014), therefore, it is in the interest of the organization itself (Qayyum et al., 2012). It influences the creation of knowledge and organizational competences, leading increased organizational innovativeness (Marimuthu et al., 2009).

Investment in human capital through employee training and development performs economic (the improvement of organization financial results) and motivational functions in the organization. An economic function is fulfilled by replacement investments (focused on maintaining the current state and quality of human capital), growth (the employment of new resources) or development (aimed at developing the qualitative features of human capital) (Lipka, 2010). A motivational function is expressed in satisfying employees' needs and motivating them to become more committed to work. Nowadays, employee commitment is increasingly appreciated and perceived as one of the determinants of organizational success, which is confirmed by many authors, e.g. M. Juchnowicz (2014), M. Bratnicki and J. Strużyna (2001). One of the methods for increasing employee commitment is also the improvement of their competencies and the creation of development opportunities (Gul, 2015). Development activities targeting employees are appreciated by them as they show that the organization takes care of employees who use their skills and make efforts to achieve organizational goals (Antonacopoulou, 2000). Investments that an organization can make to increase the value of human capital include, in particular, retention investments, related to striving for increased employee commitment in the organization's activities (Lipka, 2010).

A big challenge for the organization of the $21^{\text {st }}$ century is concern for the development of knowledge, increasing human resources and capital of their knowledge, disseminating the organizational culture of learning and providing employees with opportunities for professional development, achievements and promotion (Staniewski, 2008), which has a significant impact on the competitive position of the organization (Lee \& Bruvold, 2003). 


\section{RESEARCH METHODOLOGY}

The research process was based on the assumptions of grounded theory, according to which a research process consists of building an increasingly general theory based on systematically collected empirical data (Glaser \& Strauss, 2009). The paper presents the results of a survey conducted on a random sample of 569 employees of the Province of Silesia. The selection of the research sample was deliberate - random, so it is not representative in nature - it does not provide the basis for generalizing the conclusions for the entire population. The reference to the grounded theory in the research process makes that the research sample does not need to be statistically representative.

Among respondents, the majority were women (62.74\%), people aged 30 to $49(60.46 \%)$. Half of respondents held the position of a specialist (50.26\%), and the function of the manager was performed by $13.53 \%$ of the respondents. The overall seniority of the majority ranged from 11 to 20 years (31.99\%) and in the current organization of the respondents - up to 5 years (3.60\%). The most numerous group was people whose organization operates in the service and trade sectors as well as in education and culture (11.78\%). The smallest number of people represented industries such as protection, uniformed services, real estate, construction, media, and telecommunications. Over half of respondents $(58.17 \%)$ worked under an indefinite duration employment contract, $24.96 \%$ of respondents had a fixed-term employment contract, $6.68 \%$ of respondents were self-employed, and $4.92 \%$ of respondents had a contract of mandate. The smallest number of people performed work under a contract for specific work (1.05\%). Women had a fixedterm employment contract more often than men, while men were self-employed more often than women. People up to the age of 29 had a fixed-term employment contract and a contract of mandate more often than the elderly, while people aged at least 50 and from 30 to 49 years had an indefinite duration employment contract, more often than younger people. The longer their total seniority was, the more often they had an indefinite duration employment contract, whereas people whose work experience was up to 5 years had a fixed-term employment contract, a contract of mandate and were self-employed, more often than those with longer professional experience. People whose work experience in the current organization was up to 5 years 
had a fixed-term employment contract and a contract of mandate, more often than those with longer periods of employment; they also had an indefinite duration employment contract less frequently.

Research used a survey questionnaire, which included 12 closed and semi-open, disjunctive and conjunctive questions. The questionnaire in an electronic form was sent to 5,000 respondents, of whom 569 people filled it (response rate - 11.38\%). Empirical data were collected from December 2015 to January 2016. Statistical analysis was conducted using the SPSS software for Windows, assuming the level of significance at 0.05 . To compare people who differ in terms of the form of employment, the Kruskal-Wallis test was used.

\section{RESULTS}

The research indicated key conclusions in the area of employee training and development in the context of their form of employment. The first part of the analysis tried to answer the following questions: Do employees feel appreciated in their organizations? Do they have professional achievements/successes at work? Do they have career opportunities through work? Do they have an opportunity to be promoted? Are they interested in professional development? Do they have professional development opportunities?

The answers of respondents were grouped into certain categories: the answers definitely yes, yes and probably yes were defined as positive, the answer I do not know as neutral, and definitely not, no, and probably not as negative (Table 1).

Most of the respondents had a sense of appreciation in the organization (81.72\%) and professional achievements (85.94\%). $43.06 \%$ of them had promotion opportunities. Almost all respondents showed interest in professional development (97.89\%). Nevertheless, almost a quarter of organizations $(24.96 \%)$ did not give employees such an opportunity.

In the further part of the analysis, the relationships between the self-assessment of respondents in terms of the above mentioned categories and their form of employment were studied.

The analysis of the results showed that people who had an indefinite duration employment contract (median: 2.58) and the self-employed (median: 2.08) felt more valued employees in organizations than people 
having a fixed-term employment contract (median: 3.48) and people with a contract of mandate (median: 3.36) (Table 2).

Table 1. Self-assessment of the respondents in terms of the sense of appreciation, successes/achievements at work, development opportunities, promotion opportunities, interest in professional development and professional development opportunities in the organization

\begin{tabular}{|l|c|c|c|r|r|c|}
\hline \multirow{2}{*}{\multicolumn{1}{|c|}{ Categories rated }} & \multicolumn{7}{c|}{ Assessment } \\
\cline { 2 - 7 } & \multicolumn{2}{|c|}{ Positive } & \multicolumn{2}{c|}{ Neutral } & \multicolumn{2}{c|}{ Negative } \\
\cline { 2 - 7 } & $\mathrm{N}$ & \multicolumn{1}{c}{$\%$} & $\mathrm{~N}$ & $\%$ & $\mathrm{~N}$ & $\%$ \\
\hline Sense of appreciation & 465 & 81.72 & 0 & 0 & 104 & 18.28 \\
\hline Achievements / successes & 489 & 85.94 & 0 & 0 & 80 & 14.06 \\
\hline Development opportunities & 368 & 64.67 & 93 & 16.34 & 108 & 18.98 \\
\hline Promotion opportunities & 245 & 43.06 & 149 & 26.19 & 175 & 30.75 \\
\hline $\begin{array}{l}\text { Interest in professional employee } \\
\text { development }\end{array}$ & 557 & 97.89 & 10 & 1.76 & 2 & 0.35 \\
\hline $\begin{array}{l}\text { Professional training opportunities in } \\
\text { the organization }\end{array}$ & 362 & 63.67 & 65 & 11.42 & 142 & 24.96 \\
\hline
\end{tabular}

Source: own study.

Table 2. Current form of employment of the respondents by the assessment of the feeling of being a valued employee in the organization

\begin{tabular}{|l|c|c|c|c|c|c|c|c|c|c|}
\hline \multirow{2}{*}{ Response } & \multicolumn{7}{|c|}{ Current form of employment [number / \% of group] } \\
\cline { 2 - 13 } & $\begin{array}{c}\text { Indefinite } \\
\text { duration } \\
\text { employment } \\
\text { contract } \\
\text { (N = 331) }\end{array}$ & $\begin{array}{c}\text { Fixed-term } \\
\text { employment } \\
\text { contract } \\
(\mathrm{N}=142)\end{array}$ & $\begin{array}{c}\text { Contract of } \\
\text { mandate } \\
(\mathrm{N}=28)\end{array}$ & $\begin{array}{c}\text { Contract } \\
\text { for specific } \\
\text { work } \\
\text { (N = 6) }\end{array}$ & $\begin{array}{c}\text { Self-employ- } \\
\text { ment } \\
(\mathrm{N}=38)\end{array}$ \\
\cline { 2 - 14 } & $\mathrm{N}$ & $\%$ & $\mathrm{~N}$ & $\%$ & $\mathrm{~N}$ & $\%$ & $\mathrm{~N}$ & $\%$ & $\mathrm{~N}$ & $\%$ \\
\hline $\begin{array}{l}\text { Definitely yes } \\
\text { (N = 96) }\end{array}$ & 68 & 20.54 & 8 & 5.63 & 4 & 14.29 & 2 & 33.33 & 12 & 31.58 \\
\hline Yes (N = 164) & 106 & 32.02 & 29 & 20.42 & 5 & 17.86 & 2 & 33.33 & 15 & 39.47 \\
\hline $\begin{array}{l}\text { Probably yes } \\
\text { (N = 205) }\end{array}$ & 115 & 34.74 & 59 & 41.55 & 9 & 32.14 & 2 & 33.33 & 10 & 26.32 \\
\hline $\begin{array}{l}\text { I do not know } \\
\text { (N = 0) }\end{array}$ & - & - & - & - & - & - & - & - & - & - \\
\hline $\begin{array}{l}\text { Probably not } \\
\text { (N = 75) }\end{array}$ & 30 & 9.06 & 33 & 23.24 & 8 & 28.57 & - & - & - & - \\
\hline No (N = 12) & 6 & 1.81 & 5 & 3.52 & 1 & 3.57 & - & - & - & - \\
\hline $\begin{array}{l}\text { Definitely not } \\
\text { (N = 17) }\end{array}$ & 6 & 1.81 & 8 & 5.63 & 1 & 3.57 & - & - & 1 & 2.63 \\
\hline Mean & 2.58 & 3.48 & 3.36 & 2.00 & 2.08 \\
\hline
\end{tabular}

Source: own study. 
Respondents employed under an indefinite duration employment contract were more convinced that they have professional achievements/ successes at work than people working under a fixed-term employment contract and a contract of mandate. Self-employed respondents had a greater feeling of having professional achievements than persons having a fixed-term employment contract and people with a contract of mandate (Table 3).

Table 3. Current form of employment of respondents by the assessment of having professional achievements/successes at work

\begin{tabular}{|c|c|c|c|c|c|c|c|c|c|c|}
\hline \multirow{3}{*}{ Response } & \multicolumn{10}{|c|}{ Current form of employment [number / \% of group] } \\
\hline & \multicolumn{2}{|c|}{$\begin{array}{c}\text { Indefinite } \\
\text { duration } \\
\text { employment } \\
\text { contract } \\
(\mathrm{N}=331)\end{array}$} & \multicolumn{2}{|c|}{$\begin{array}{c}\text { Fixed-term } \\
\text { employment } \\
\text { contract } \\
(\mathrm{N}=142)\end{array}$} & \multicolumn{2}{|c|}{$\begin{array}{l}\text { Contract of } \\
\text { mandate } \\
(\mathrm{N}=28)\end{array}$} & \multicolumn{2}{|c|}{$\begin{array}{c}\text { Contract } \\
\text { for specific } \\
\text { work } \\
(\mathrm{N}=6)\end{array}$} & \multicolumn{2}{|c|}{$\begin{array}{c}\text { Self-employ- } \\
\text { ment } \\
(\mathrm{N}=38)\end{array}$} \\
\hline & $\mathrm{N}$ & $\%$ & $\mathrm{~N}$ & $\%$ & $\mathrm{~N}$ & $\%$ & $\mathrm{~N}$ & $\%$ & $\mathrm{~N}$ & $\%$ \\
\hline $\begin{array}{l}\text { Definitely yes } \\
(\mathrm{N}=129)\end{array}$ & 88 & 26.59 & 15 & 10.56 & 4 & 14.29 & 1 & 16.67 & 16 & 42.11 \\
\hline Yes $(\mathrm{N}=224)$ & 140 & 42.30 & 52 & 36.62 & 5 & 17.86 & 3 & 50.00 & 11 & 28.95 \\
\hline $\begin{array}{l}\text { Probably yes } \\
(\mathrm{N}=136)\end{array}$ & 71 & 21.45 & 35 & 24.65 & 12 & 42.86 & 2 & 33.33 & 11 & 28.95 \\
\hline $\begin{array}{l}\text { I do not know } \\
(\mathrm{N}=0)\end{array}$ & - & - & - & - & - & - & - & - & - & - \\
\hline $\begin{array}{l}\text { Probably not } \\
(\mathrm{N}=60)\end{array}$ & 25 & 7.55 & 30 & 21.13 & 4 & 14.29 & - & - & - & - \\
\hline No $(\mathrm{N}=18)$ & 6 & 1.81 & 9 & 6.34 & 3 & 10.71 & - & - & - & - \\
\hline $\begin{array}{l}\text { Definitely not } \\
(\mathrm{N}=2)\end{array}$ & 1 & 0.30 & 1 & 0.70 & - & - & - & - & - & - \\
\hline Mean & \multicolumn{2}{|c|}{2.26} & \multicolumn{2}{|c|}{3.06} & \multicolumn{2}{|c|}{3.14} & \multicolumn{2}{|c|}{2.17} & \multicolumn{2}{|c|}{1.87} \\
\hline
\end{tabular}

Source: own study.

The self-employed and those who work under an indefinite duration employment contract were most convinced of professional development opportunities and the least - persons working under a contract of mandate. An analysis by the Kruskal-Wallis test showed statistically significant differences. Those who have an indefinite duration employment contract were more convinced that their work provides them with professional development opportunities than those who have a fixed-term employment contract $(\mathrm{p}<0.001)$. The self-employed were more convinced that the work performed provides them with the 
opportunity to develop professionally than people who have a fixed-term employment contract $(p=0.001)$ and people working under a contract of mandate $(\mathrm{p}=0.041)($ Table 4$)$.

Table 4. Current form of employment of respondents by the assessment of professional development opportunity

\begin{tabular}{|c|c|c|c|c|c|}
\hline Variable & $\begin{array}{l}\text { Current form } \\
\text { of employment }\end{array}$ & Mean & $\begin{array}{l}\text { Standard } \\
\text { deviation }\end{array}$ & $\begin{array}{l}\mathrm{K}-\mathrm{W} \text { test } \\
\text { result }\end{array}$ & $\begin{array}{c}\text { Significance } \\
\text { level }\end{array}$ \\
\hline \multirow{5}{*}{$\begin{array}{l}\text { Assessment } \\
\text { of professional } \\
\text { development } \\
\text { opportunities } \\
\text { by the work } \\
\text { performed }\end{array}$} & $\begin{array}{l}\text { Indefinite duration } \\
\text { employment contract }\end{array}$ & 2.81 & 1.54 & \multirow{5}{*}{34.75} & \multirow{5}{*}{$<0.001$} \\
\hline & $\begin{array}{l}\text { Fixed-term employ- } \\
\text { ment contract }\end{array}$ & 3.58 & 1.75 & & \\
\hline & Contract of mandate & 3.68 & 1.81 & & \\
\hline & $\begin{array}{l}\text { Contract for specific } \\
\text { work }\end{array}$ & 2.83 & 1.33 & & \\
\hline & Self-employment & 2.29 & 1.23 & & \\
\hline
\end{tabular}

Source: own study.

People working under an indefinite duration employment contract were most convinced of promotion opportunities in organizations. The Kruskal-Wallis test showed that respondents with the indefinite duration employment contract were more convinced of promotion opportunity in the organization than those who had a fixed-term employment contract $(\mathrm{p}=0.002)$ (Table 5).

Table 5. Current form of employment and the assessment of promotion opportunities in the organization

\begin{tabular}{|c|c|c|c|c|c|}
\hline Variable & $\begin{array}{l}\text { Current form } \\
\text { of employment }\end{array}$ & Mean & $\begin{array}{l}\text { Standard } \\
\text { deviation }\end{array}$ & $\begin{array}{l}\mathrm{K}-\mathrm{W} \text { test } \\
\text { result }\end{array}$ & $\begin{array}{l}\text { Significance } \\
\text { level }\end{array}$ \\
\hline \multirow{5}{*}{$\begin{array}{l}\text { Assessment } \\
\text { of promotion } \\
\text { opportunities in } \\
\text { the organization }\end{array}$} & $\begin{array}{l}\text { Indefinite duration } \\
\text { employment contract }\end{array}$ & 3.44 & 1.59 & \multirow{5}{*}{23.83} & \multirow{5}{*}{0.002} \\
\hline & $\begin{array}{l}\text { Fixed-term employ- } \\
\text { ment contract }\end{array}$ & 4.10 & 1.65 & & \\
\hline & Contract of mandate & 4.07 & 1.46 & & \\
\hline & $\begin{array}{l}\text { Contract for specific } \\
\text { work }\end{array}$ & 4.17 & 1.33 & & \\
\hline & Self-employment & 3.92 & 1.51 & & \\
\hline
\end{tabular}

Source: own study.

An analysis by the Kruskal-Wallis test showed that the self-employed and those who had an indefinite duration employment contract 
were most convinced of the opportunities of improving professional competencies in organizations. Such opportunities were rated the lowest by those working under a contract of mandate and a contract for specific work. Statistically significant differences were observed in a few cases. People who have an indefinite duration employment contract were more convinced that they have the opportunity to improve their professional competencies in the organization than people who have a fixed-term employment contract $(p<0.001)$. The self-employed claimed that they had greater opportunities to improve their professional competencies in the organization than persons who have a fixed-term employment contract $(p<0.001)$ and those working under a contract of mandate $(p=0.007)$ (Table 6).

Table 6. Current form of employment and the assessment of professional training opportunity in the organization

\begin{tabular}{|c|l|c|c|c|c|}
\hline \multirow{2}{*}{ Variable } & \multicolumn{1}{|c|}{$\begin{array}{c}\text { Current form of } \\
\text { employment }\end{array}$} & Mean & $\begin{array}{c}\text { Standard } \\
\text { deviation }\end{array}$ & $\begin{array}{c}\text { K-W test } \\
\text { result }\end{array}$ & $\begin{array}{c}\text { Significance } \\
\text { level }\end{array}$ \\
\hline \multirow{2}{*}{$\begin{array}{l}\text { Assessment of } \\
\text { professional } \\
\text { training } \\
\text { opportunities }\end{array}$} & $\begin{array}{l}\text { Indefinite duration } \\
\text { employment contract }\end{array}$ & 2.87 & 1.60 & & \\
\cline { 2 - 4 } & $\begin{array}{l}\text { Fixed-term employ- } \\
\text { ment contract }\end{array}$ & 3.80 & 1.77 & \multirow{2}{*}{49.36} & $<0.001$ \\
\cline { 2 - 4 } & Contract of mandate & 4.00 & 1.85 & & \\
\cline { 2 - 4 } & $\begin{array}{l}\text { Contract for specific } \\
\text { work }\end{array}$ & 4.00 & 1.10 & & \\
\cline { 2 - 4 } & Self-employment & 2.32 & 1.25 & & \\
\hline
\end{tabular}

Source: own study.

The third part of the analysis tested which forms of professional training employees can participate in. The results obtained showed that respondents usually participated in the training forms such as on-the-job training for a larger group of employees and off-the-job training. In organizations, employees could also participate in individual on-demand and e-learning training. Coaching and mentoring were very rarely used. A small percentage of respondents did not participate in any form of training (Table 7).

To sum up, the results obtained showed that the majority of respondents had the feeling of being valued employees in their organizations and were successful or had professional achievements. However, these statements concerned mainly people who had an indefinite duration employment contract and were self-employed. People who worked 
under a fixed-term employment contract and a contract of mandate had a similar feeling, but to a lesser extent. The situation was the same as regards the conviction of respondents of professional development opportunities in their parent organizations. Although a significant percentage of respondents had the sense of appreciation in the organization, career opportunities and having professional achievements, there were significantly fewer people expecting promotion in organizations. However, the majority of them were employed under an indefinite duration employment contract. Although almost all respondents were interested in improving their professional competencies, organizations did not offer such opportunities to all employees. People working under an indefinite duration employment contract and the self-employed had the greatest opportunities. Employees usually participated in on-thejob and off-the-job training. Many organizations also responded to the wishes of employees for their participation in individual training. Few respondents participated in coaching or mentoring, which indicates the little popularity of these forms of employee training.

Table 7. Participation of respondents in various forms of professional training

\begin{tabular}{|l|c|c|}
\hline Response & Number & Percentage \\
\hline Off-the-job training & 264 & 46.40 \\
\hline On-the-job training for a larger group of employees & 299 & 52.55 \\
\hline Individual training at the request of individual employees & 145 & 25.48 \\
\hline Postgraduate studies & 108 & 18.98 \\
\hline Language courses & 82 & 14.41 \\
\hline Conferences, scientific/industry seminars & 115 & 20.21 \\
\hline Third-cycle (doctoral) studies & 4 & 0.70 \\
\hline Coaching & 53 & 9.31 \\
\hline Mentoring & 23 & 4.04 \\
\hline E-learning training & 133 & 23.37 \\
\hline Other & 111 & 19.51 \\
\hline I do not participate in any form of professional training & 18 & 3.16 \\
\hline
\end{tabular}

Source: own study. 


\section{DISCUSSION}

The research presented in this paper refers to a classic question whether it is profitable and reasonable to invest in the development of employee skills in different organizations. The high costs of employee professional development result in the fact that many organizations would opt for reducing their responsibility for the professional development of their staff. Moreover, the concept of a "transaction approach" has been increasingly popular among organizations recently. It assumes "buying" the certain competence potential by the organization and requires no development actions taken by this organization at the same time (Thijssen et al., 2008). According to this concept, it is the employee who bears the main responsibility for their skill development and improvement of their professional potential. On the other hand, the lack of investment in the development of employee skills may significantly affect their motivation and result in their decision to resign from the job. The lack of development opportunities from the employee perspective, in the situation when knowledge and skills become rapidly outdated nowadays, may force these employees to search for new development opportunities in other organizations, as currently employees are much more interested in learning new skills in the workplace rather than look for a stable and long term employment opportunity. As research indicates, a surprising fact is that employers are more keen on investing in employees that are hired based on more stable forms of employment.

The results obtained indicate that there is a relationship between the form of employment of employees and their development opportunities. Previous research shows the positive impact of improving employee competencies both on employees themselves (their performance and efficiency) and on organizations (employee training leads to return on investment and influences employee retention positively) (Becker, 1993; Colarelli \& Montei, 1996; Asfaw et al., 2015). Thus, as research shows, fewer development opportunities for employees working under flexible forms of employment may lead to less employee commitment. By blocking employee development opportunities, organizations may also have an adverse impact on the retention of employees who, having no possibility of development in the organization, may leave it. Employee development affects their performance, and thus the performance of the 
entire organization and effectiveness in achieving goals. If employees feel the effects in the field of professional development and achieve success at work, it motivates them to improve continuously, boosts their confidence in their own competencies (Schaffer \& Thomson, 1992), and improves their self-esteem (Saleem et al., 2011). Training and development benefits individual employees, encourages them to make better decisions and solve problems effectively, helping them achieve self-improvement and self-confidence. It helps employees cope with stress, tension, frustration and conflict, and increases their job satisfaction (Tahir et al., 2014). Thus, those employed under flexible contracts may have problems with their self-esteem and self-confidence, and therefore also with facing challenges and solving problem effectively. They may also be less satisfied with their work. Development opportunities are one of important factors that determine the attractiveness of work. Other research has shown that the employees' perception of the organizational support in professional training and development is an element that builds trust in the organization (Foong Ming, 2008). It has also been shown that learning and development opportunities are more important to employees than financial benefits, job satisfaction and relationships with colleagues (McNeese-Smith, 2001). It seems, therefore, that employees who work under the alternative forms of employment, who an employer does not invest in by enabling them to develop and improve their professional skills, are in a weaker position in the organization and show less trust in it.

\section{CONCLUSIONS}

The analysis of relationships, conducted as part of research, indicated statistically significant differences between the following: the form of employment and the assessment of employee development opportunities $(p<0.001)$, the form of employment and the assessment of employee promotion opportunities in the organization $(p=0.002)$, the form of employment and the assessment of employee training opportunities $(p<0.001)$. Although from the point of view of employers the use of flexible forms of employment is only an advantage for the organization (Gunnigle et al., 1998), some losses that a company can make can be shown, when we look at the problem of flexibility in terms of human capital and knowledge in the organization. It should be noted that 
stabilization of employment (especially a secure work contract) may be a more important motivating factor to work (Szczepańska-Woszczyna, 2015). Persons working under less stable forms of employment may be perceived as less associated with the organization, so perhaps the organization refuses to invest in such employees. However, all employees ensure that the organization achieves the goals set (Taylor, 2006). The basis of the above assumptions is a belief in the potential inherent in each employee. Therefore, each employee, regardless of the form of employment, should have an opportunity for professional training and development in the organization.

Although the research results obtained cannot form the basis for their generalization to the entire population, they contribute to further, more in-depth research in this field. It seems reasonable to learn the reasons why employers are less interested in offering training and creating development opportunities for employees working under less stable forms of employment.

The implications of the conducted research for managers managing employees in organizations concern the study of the issues of training and development of also such employees that work for the organization under the flexible forms of employment, for example under a contract of mandate. No investment in people, who are the highest value and asset of the company, may result in their less commitment in work, poorer performance and a shortage of employees with appropriate qualifications.

\section{REFERENCES}

Antonacopoulou, E.P. (2000). Employee development through self-development in three retail banks. Journal of Personnel Review, 29(4).

Asfaw, A.M., Argaw, M.D. \& Bayissa, L. (2015). The impact of training and development on employee performance and effectiveness: A case study of District Five Administration Office, Bole Sub-City, Addis Ababa, Ethiopia. Journal of Human Resource and Sustainability Studies, 3.

Bataineh, K.A.A. (2014). Impacts of Employee Training on the Performance of Commercial Banks in Jordan. European Journal of Business and Management, 6(27).

Batra, S. (2009). Strengthening human capital for knowledge economy needs: An Indian perspective. Journal of Knowledge Management, 13. 
Becker, G.S. (1993). Human Capital: A Theoretical and Empirical Analysis with Special Reference to Education. Chicago: University of Chicago Press.

Becker, G., Murphy, K. \& Tamura, R. (1990). Human capital, fertility and economic growth. Journal of Political Economy, 98.

Bratnicki, M. \& Strużyna, J. (2001). Kapitał ludzki - krok w kierunku nowej perspektywy człowieka w przedsiębiorczej organizacji. In: M. Bratnicki \& J. Strużyna (eds.), Przedsiębiorczość i kapitat intelektualny, Katowice: Wydawnictwo Akademii Ekonomicznej.

Burke, M.E. (2011). Knowledge sparing in emerging economies. Library Review, 60(1).

Cho, Y. \& Won Yoon, S. (2010). Theory development and convergence of human resource fields: Implications for human performance technology. Performance Improvement Quarterly, 23.

Colarelli, S.M. \& Montei, M.S. (1996). Some contextual influences on training utilization. The Journal of Applied Behavioral Science, 32(3).

Elnaga, A. \& Imran, A. (2013). The effect of training on employee performance. European Journal of Business and Management, 5(4).

Falola, H.O., Osibanjo, A.O. \& Ojo, S.I. (2014). Effectiveness of training and development on employees' performance and organization competitiveness in the Nigerian banking industry. Bulletin of the Transilvania University of Braşov Series V: Economic Sciences, 7/56(1).

Filipowicz, G. (2006). Zarządzanie pracownikami w organizacjach o elastycznych strukturach i zatrudnieniu. In: S. Borkowska (ed.), Zarzadzanie zasobami ludzkimi. Teraźniejszość i przyszłość. Warszawa: Instytut Pracy i Spraw Socjalnych.

Foong Ming, T. (2008). Organisational support as the mediator of career-related HRM practices and affective commitment: Evidence from knowledge workers in Malaysia. Research and Practice in Human Resource Management, 16.

Glaser, B. \& Strauss, A. (2009). Odkrywanie teorii ugruntowanej. Kraków: Zakład Wydawniczy „Nomos”.

Griffin, R. (1996). Podstawy zarzadzania organizacjami. Warszawa: Wydawnictwo Naukowe PWN.

Gul, Z. (2015). Impact of employee commitment on organizational development. FWU Journal of Social Sciences, 9(2).

Gunnigle, P., Turner, T. \& Morley, M. (1998). Employment flexibility and industrial relations arrangements at organization level: A comparison of five European countries. Employee Relations, 20(5).

Hameed, A. \& Waheed, A. (2011). Employee development and its affect on employee performance: A conceptual framework. International Journal of Business and Social Science, 2(13). 
Imran, M. \& Tanveer, A. (2015). Impact of training \& development on employees' performance in banks of Pakistan. European Journal of Training and Development Studies, 3(1).

Juchnowicz, M. (2014). Zaangażowanie pracowników. Sposoby oceny i motywowania. Warszawa: Polskie Wydawnictwo Ekonomiczne.

Kożusznik, B. \& Adamiec, M. (2000). Zarzqdzanie zasobami ludzkimi. Aktor - kreator - inspirator. Katowice: Wydawnictwo Akade.

Lee, C.H. \& Bruvold, N.T. (2003). Creating value for employees: Investment in employee development. The International Journal of Human Resource Management, 14(6).

Lipka, A. (2010). Inwestycje w kapitat ludzki organizacji w okresie koniunktury $i$ dekoniunktury. Warszawa: Oficyna a Wolters Kluwer business

Marimuthu, M., Arokiasamy, L. \& Ismail, M. (2009). Human capital development and its impact on firm performance: Evidence from developmental economics. The Journal of International Social Research, 2(8).

Matthews, J.J., Megginson, D. \& Surtees, M. (2008). Rozwój zasobów ludzkich, transl. A. Czardybon, M. Strzelecka. Gliwice: Onepress.

McNeese-Smith, D.K. (2001). A nursing shortage: Building organizational commitment among nurses. Journal of Healthcare Management, 46(3).

Psarras, J. (2006). Education and training in the knowledge-based economy. The Journal of Information and Knowledge Management Systems, 36(1).

Pedrini, M. (2007). Human capital convergences in intellectual capital and sustainability reports. Journal Intellectual Capital, 8(2).

Qayyum, A., Sharif, M.T., Ahmad, A., Khan, M.S. \& Rehman, K. (2012). Training $\&$ development practices in National Bank of Pakistan. Information Management and Business Review, 4(1).

Saleem, Q., Shahid, M. \& Naseem, A. (2011). Degree of influence of training and development on employees' behavior. International Journal of Computing and Business Research, 2(3).

Schaffer, R. \& Thomson, H. (1992). Successful change programs begin with results. Harvard Business Review, 70(1), 80-89.

Staniewski, M. (2008). Zarzqdzanie zasobami ludzkimi a zarzqdzanie wiedzq $w$ przedsiębiorstwie. Warszawa: Vizja Press \& IT.

Sutherland, J. \& Canwell, D. (2007). Klucz do zarzadzania zasobami ludzkimi. Warszawa: Wydawnictwo Naukowe PWN.

Szałkowski, A. (ed.) (2006). Podstawy zarzadzania personelem. Kraków: Wydawnictwo Akademii Ekonomicznej.

Szczepańska-Woszczyna, K. (2015). Leadership and organizational culture as the normative influence of top management on employee's behaviour in the innovation process. Procedia Economics and Finance, 34. 
Szczepańska-Woszczyna, K. \& Dacko-Pikiewicz, Z. (2014). Managerial competencies and innovations in the company - the case of enterprises in Poland. Business, Management and Education, 12(2).

Szczepańska-Woszczyna, K., Dacko-Pikiewicz, Z. \& Lis, M. (2015). Responsible leadership: A real need or transient curiosity. Procedia-Social and Behavioral Sciences, 213.

Szczepańska-Woszczyna, K. \& Kurowska-Pysz, J. (2016). Sustainable business development through leadership. Economics and Management, 8(3).

Tahir, N., Yousafzai, I.K., Jan, S. \& Hashim, M. (2014). The impact of training and development on employees performance and productivity: A case study of United Bank Limited Peshawar City, KPK, Pakistan. International Journal of Academic Research in Business and Social Sciences, 4(4).

Taylor, S. (2006). Płynność zatrudnienia. Jak zatrzymać pracowników w firmie. Kraków: Wolters Kluwer Polska.

Thijssen, J.G.L., Van Der Heijden, B.I.J.M. \& Rocco, T.S. (2008). Toward the employability-link model: Current employment transition to future employment perspectives. Human Resource Development Review, 7(2).

Wang, C.L. \& Ahmed, P.K. (2003). Managing Knowledge Workers. Working Paper Series, Management Research Centre, University of Wolverhampton, Shropshire.

Vinesh, K. (2014). Role of training \& development in an organizational development. International Journal of Management and International Business Studies, $4(2)$. 


\section{ZWIAZZEK POMIĘDZY FORMĄ ZATRUDNIENIA A SZKOLENIEM I MOŻLIWOŚCIAMI ROZWOJU PRACOWNIKÓW W ORGANIZACJI}

We współczesnych organizacjach coraz częściej podkreśla się wagę doskonalenia i rozwoju pracowników w celu podwyższenia ich kwalifikacji oraz nabywania nowych kompetencji wiedzy, a także rozwijania przydatnych dla organizacji postaw. W organizacjach coraz częściej stosowane sa jednak elastyczne, mniej trwałe niż umowa o pracę na czas nieokreślony formy zatrudnienia. Celem artykułu jest przedstawienie zależności pomiędzy formą zatrudnienia a możliwościami doskonalenia i rozwoju pracowników w organizacjach. Zaprezentowano w nim wyniki badania przeprowadzonego metodą sondażu diagnostycznego z wykorzystaniem kwestionariusza ankiety wśród 569 pracowników województwa ślaskiego. Proces badawczy został przeprowadzony na podstawie teorii ugruntowanej, zaś analizy statystyczne wykonano za pomoca programu SPSS for Windows, przyjmując poziom istotności 0,05. W celu porównania osób różniących się formą zatrudnienia wykorzystano test Kruskala-Wallisa. Uzyskane wyniki badań wskazały na istnienie pewnych zależności pomiędzy forma zatrudnienia a możliwościami doskonalenia i rozwoju pracowników w organizacji. Wykazano istnienie istotnych statystycznie różnic między: formą zatrudnienia a ocena możliwości rozwoju pracowników, formą zatrudnienia a oceną możliwości awansu pracowników w organizacji oraz formą zatrudnienia a oceną możliwości doskonalenia zawodowego pracowników.

Słowa kluczowe: kapitał ludzki, rozwój zawodowy, szkolenie, forma zatrudnienia. 